\title{
PERAN MUSYAWARAH GURU MATA PELAJARAN DALAM MENINGKATKAN PENGEMBANGAN PROFESIONALISME GURU PENDIDIKAN AGAMA ISLAM SMA DI KABUPATEN JOMBANG
}

\author{
Muhamad Khoirur Roziqin*1 \\ Program Studi Pendidikan Agama Islam \\ Universitas KH. A. Wahab Hasbullah Jombang \\ Email: indra@unwaha.ac.id \\ Sholeh Abdul Baqi \\ Program Studi Pendidikan Agama Islam \\ Universitas KH. A. Wahab Hasbullah Jombang \\ Email: santrisaidiyah2@gmail.com
}

\begin{abstract}
This study aims 1.) to find out Islamic Religious Education Subjects at the Jombang Regency State High School, 2.) to find out how the role of Subject Teacher Guidance in improving the professionalism of Islamic Religious Education Teachers in high school in Jombang Regency. This research is a qualitative research, which uses research procedures that produce descriptive data in the form of written or spoken words from organizations and behaviors that are observed and directed at natural settings and individuals holistically (as a whole). The research data were then analyzed using descriptive analysis, namely the analysis of data displayed in the form of descriptive reports and descriptions, using inductive thinking. Inductive thinking is a way of drawing conclusions from empirical facts and then drawing generalizations. The results obtained from the Subject Teacher Meetings include: 1. The growing willingness of PAI teachers to always improve their performance as teachers by following existing positive changes, 2. PAI teachers are motivated to become better because they relate a lot to other people so that insight becomes increased. 3. Islamic religious education teachers know the latest news or issues in the world of education because the Subject Teacher Consultation is a mediator from the national education office and the department of religion in delivering the implementation of education policies, curriculum changes, and others. 4. With training and upgrading, the creativity and skills of Islamic Religious Education teachers will develop and be honed.
\end{abstract}

Keywords: Professionalism, Teacher, MGMP

\begin{abstract}
Abstrak
Penelitian ini bertujuan 1.) untuk mengetahui Mata Pelajaran Pendidikan Agama Islam setingkat SMA Negeri Kabupaten Jombang, 2.) untuk mengetahui bagaimana peran Bimbingan Guru Mata Pelajaran dalam meningkatkan profesionalisme Guru Pendidikan Agama Islam SMA di Kabupaten Jombang. Penelitian ini merupakan penelitian kualitatif, yang menggunakan prosedur penelitian yang menghasilkan data deskriptif berupa kata-kata
\end{abstract}




\section{Muhamad Khoirur Roziqin, Sholeh Abdul Baqi.}

tertulis atau lisan dari organisasi dan perilaku yang diamati dan diarahkan pada setting alam dan individu secara holistik (secara keseluruhan). Data penelitian kemudian dianalisis menggunakan analisis deskriptif, yaitu analisis data yang ditampilkan dalam bentuk laporan deskriptif dan deskripsi, dengan menggunakan pemikiran induktif. Berpikir induktif adalah cara menarik kesimpulan dari fakta empiris dan kemudian menarik generalisasi. Hasil yang diperoleh dari Musyawarah Guru Mata Pelajaran antara lain: 1. Tumbuhnya kemauan guru PAI untuk selalu meningkatkan kinerjanya sebagai guru dengan mengikuti perubahanperubahan positif yang ada, 2. Guru PAI termotivasi untuk menjadi lebih baik karena banyak berhubungan dengan orang lain sehingga wawasan menjadi meningkat. 3. Guru pendidikan agama Islam mengetahui berita atau isu terkini dalam dunia pendidikan karena Musyawarah Guru Mata Pelajaran merupakan mediator dari dinas pendidikan nasional dan departemen agama dalam penyampaian penyelenggaraan kebijakan pendidikan, perubahan kurikulum, dan lain-lain. 4. Dengan pelatihan dan penataran, kreativitas dan keterampilan guru Pendidikan Agama Islam akan berkembang dan terasah.

Kata kunci: Profesionalisme, Guru, MGMP.

\section{A. PENDAHULUAN}

Pendidikan nasional memiliki peranan yang sangat penting bagi warga negara. Pendidikan nasional bertujuan untk mencerdaskan kehidupan bangsa dan mengembangkan manusia Indonesia seutuhnya, yaitu manusia yang beriman dan bertakwa terhadap Tuhan Yang Maha Esa dan berbudi pekerti luhur, memiliki pengetahuan dan keterampilan, kesehatan jasmani dan rohani, kepribadian yang mantap dan mandiri serta rasa tanggung jawab kemasyarakatan dan kebangsaan. Oleh karena itu setiap warga negara berhak untuk mendapatkan pendidikan. Sebagaimana tercantum dalam Undang Undang Dasar 1945 pasal 31 ayat 1 dan Undang-Undang Nomor 20 tahun 2003 tentang Sistem Pendidikan Nasional bab 
IV pasal 5 ayat 1 menyatakan bahwa setiap warga negara mempunyai hak yang sama untuk memperoleh pendidikan yang bermutu. ${ }^{1}$

Pembelajaran yang bermutu akan bermuara pada kemampuan guru dalam proses pembelajaran. Secara sederhana kemampuan yang harus dimiliki oleh guru yaitu kemampuan merencanakan pembelajaran, proses pembelajaran, serta evaluasi pembelajaran. Mutu pembelajaran adalah ukuran yang menunjukkan seberapa tinggi mutu interaksi guru dengan siswa dalam proses pembelajaran dalam rangka pencapaian tujuan tertentu. Proses interaksi ini dimungkinkan karena manusia merupakan mahluk sosial yang membutuhkan orang lain dalam kehidupannya. ${ }^{2}$ Salah satu faktor yang memiliki peran sentral dalam peningkatan kualitas pendidikan nasional adalah mutu pendidik atau guru. Menurut Zamroni bahwa tugas guru adalah mengembangkan potensi siswa secara maksimal melalui penyajian mata pelajaran. ${ }^{3}$ Selanjutnya menurut Nurdin bahwa dalam sebuah proses pendidikan, guru merupakan salah satu komponen yang sangat penting selain komponen lainnya, serta guru mempunyai tiga hubungan dengan peserta didik, yaitu hubungan instruksional, hubungan emosional, dan hubungan spiritual. ${ }^{4}$

1 Undang-Undang Sistem Pendidikan Nasional Guru Dan Dosen (Tangerang: PT. Agro Media Pustaka, 2007).

2 Asep Kalimantara et al., Kompetensi Kewirausahaan Kepala Sekolah Dan Implikasinya Pada Peningkatan Mutu Guru Dalam Pembelajaran Di SD Negeri Nugraha Pelita Jalancagak Kabupaten Subang, Jurnal Penelitian Guru FKIP Universitas Subang, vol. 03, n.d.

${ }^{3}$ Langgau and Yulius Mataputun, "Peranan Mgmp Dalam Meningkatkan Profesionalisme Guru Bahasa Inggris SMP Di Kota Jayapura," Jurnal MAPENDIK-Magister Manajemen Pendidikan Uncen 03, no. 01 (2016): 81-88.

${ }^{4}$ Ibid. 


\section{Muhamad Khoirur Roziqin, Sholeh Abdul Baqi.}

Dalam pendidikan, Proses Belajar Mengajar (PBM) merupakan inti dari proses pendidikan secara keseluruhan dengan guru sebagai pemegang peran utamanya. Upaya untuk meningkatkan kualitas guru agar berkembang dan dapat melaksanakan fungsinya secara profesional terus-menerus mencapai tujuan sesuai dengan kurikulum yang ada telah ditetapkan oleh Pemerintah. Salah satu upaya untuk meningkatkan kualitas guru adalah melalui forum Musyawarah Guru Mata Pelajaran (MGMP), sebuah organisasi profesi yang menghimpun guru mata pelajaran sejenis.

Tujuan pembentukan MGMP yang tertuang dalam Standar Pengembangan MGMP adalah sebagai berikut:

1. Memperluas wawasan dan pengetahuan guru dalam berbagai hal, khususnya penguasaan substansi materi pelajaran, penyusunan silabus, penyusunan bahan-bahan pembelajaran, strategi pembelajaran, metode pembelajaran, memaksimalkan pemakaian sarana/prasarana belajar, memanfaatkan sumber belajar, dsb.

2. Memberi kesempatan kepada anggota kelompok kerja atau musyawarah kerja untuk berbagi pengalaman serta saling memberikan bantuan dan umpan balik.

3. Meningkatkan pengetahuan dan keterampilan, serta mengadopsi pendekatan pembaharuan dalam pembelajaran yang lebih profesional bagi peserta kelompok kerja atau musyawarah kerja. 
4. Memberdayakan dan membantu anggota kelompok kerja dalam melaksanakan tugas-tugas pembelajaran di sekolah.

5. Mengubah budaya kerja anggota kelompok kerja atau musyawarah kerja (meningkatkan pengetahuan, kompetensi dan kinerja) dan mengembangkan profesionalisme guru melalui kegiatan-kegiatan pengembangan profesionalisme di tingkat MGMP.

6. Meningkatkan mutu proses pendidikan dan pembelajaran yang tercermin dari peningkatan hasil belajar peserta didik.

7. Meningkatkan kompetensi guru melalui kegiatan-kegiatan di tingkat MGMP. ${ }^{5}$

Berkaitan dengan peran forum pertemuan guru di MGMP yang sangat strategis untuk peningkatan kompetensi guru dan kinerja guru, maka pemberdayaan MGMP merupakan hal mendesak yang harus segera dilakukan. Berbagai upaya untuk meningkatkan kinerja guru, antara lain melalui berbagai pelatihan instruktur, peningkatan sarana dan prasarana, dan peningkatan mutu manajemen MGMP. Laporan evaluasi pelaksanaan kegiatan MGMP PAI Tingkat SMA di Jombang menyebutkan, masih banyak MGMP PAI yang belum menunjukkan peningkatan kinerja yang berarti. Di beberapa daerah peningkatan kinerja MGMP PAI cukup menggembirakan, namun di sebagian besar daerah lainnya masih memprihatinkan. Namun, dalam penelitian sebelumnya, penulis tidak menemukan adanya pembinaan yang dibekali untuk para guru agar dapat

\footnotetext{
${ }^{5}$ Depdiknas, “Panduan Pengembangan Bahan Ajar Depdiknas 2008” (2008): 1-4.
} 


\section{Muhamad Khoirur Roziqin, Sholeh Abdul Baqi.}

berperan aktif dalam menghasilkan peserta didik yang aktif dan inovatif. Selain itu, objek penelitiannya masih sempit sehingga penulis merasa perlu melakukan penelitian dengan objek penelitian yang lebih luas.

\section{B. METODE PENELITIAN}

Penelitian ini merupakan penelitian lapangan (Field Research) artinya penelitian ini mengambil data autentik secara objektif, dengan menggunakan metode kualitatif yaitu metode penelitian yang digunakan untuk meneliti pada kondisi obyek yang alamiah, dimana penelitian sebagai instrumen kunci, analisis data bersifat induktif, dan hasil penelitian kualitatif lebih menekankan makna. ${ }^{6}$ Penelitian kualitatif ini bersifat induktif yaitu maksudnya peneliti ini membiarkan permasalahan muncul dari data. Maka dari itu peneliti sebagai instrumen utama melaksanakan penelitian pada kondisi yang alamiah, dan langsung ke sumber data. Penelitian yang digunakan bersifat deskriptif, datanya berbentuk kata-kata dari hasil wawancara, observasi dan analisis dokumen, untuk menambah dan memperkuat data selain metode observasi dan metode wawancara yang dikumpulkan dalam hipotesa. Dari uraian diatas maka penulis menggunakan metode deskriptif kualitatif, dalam penelitian ini dengan maksud untuk memperoleh gambaran tentang metode dalam meningkatan peran pengembangan Profesi Guru Pendidikan Agama Islam di MGMP SMA wilayah

${ }^{6}$ Machnunah Ani Zulfah, "Pendidikan Seks Pada Anak Dalam Islam," At-Tahdzib Jurnal Studi Islam dan Muamalah 1, no. 1 (2017): 150-171. 
Kabupaten Jombang. ${ }^{7}$ Analisis data kualitatif dilakukan secara interaktif dan berlangsung terus menerus sampai tuntas. Analisis data yang digunakan peneliti adalah analisis data model Miles Huberman yang meliputi reduksi data, display data, penarikan kesimpulan dan verifikasi. ${ }^{8}$ Langkah-langkah analisis data tersebut dapat digambarkan dengan skema berikut: Pengumpulan Data (Data Collection), Reduksi Data (Data Reduction), Penyajian Data (Data Display), Penarikan Kesimpulan dan Verifikasi (Conclusion, Verifying).

\section{HASIL PENELITIAN}

Berdasarkan data diagram diatas menunjukan bahwa rata-rata nilai pre test adalah 49 dan rata-rata nilai post test 80 . Maka nilai post tes menunjukan lebih bagus dari nilai pre test. Dan dapat disimpulkan bahwa media kamus saku Arab-Indonesia ini efektif digunakan dan dapat meningkatkan kemampuan membaca santri Pondok Pesantren Roudhotul Quran An-Noer.

Dari hasil Observasi dan analisis ini, sedikitnya ada empatfaktor yang menyebabkan kinerja MGMP secara umum dapat mengalami peningkatan pengembangan secara merata. ${ }^{9}$ Faktor pertama, kebijakan dan penyelenggaraan MGMP menggunakan pendekatan education production function atau inputoutput analysis yang dilaksanakan secara konsekuen. Pendekatan ini melihat bahwa MGMP berfungsi sebagai pusat produksi yang apabila dipenuhi semua

\footnotetext{
7 Sugiyono, Metode Penelitian Kuantitatif, Kualitatif Dan RED, ed. IKAPI (Bandung: Bandung: Alfabeta, 2016).

${ }^{8}$ Ibid.

9 “Peranan MGMP Dalam Ikan Agama Islam SMA Di," n.d.
} 


\section{Muhamad Khoirur Roziqin, Sholeh Abdul Baqi.}

input (masukan) yang diperlukan dalam kegiatan pengembangan tersebut, maka lembaga ini akan menghasilkan output yang dikehendaki. Pendekatan ini menganggap bahwa apabila input MGMP seperti pelatihan guru dan perbaikan sarana dan prasarana lainnya dipenuhi, maka hasil peningkatan kinerja pengembangan pembelajaran MGMP secara otomatis akan terjadi. Dalam kenyataan, peningkatan kinerja MGMP yang diharapkan tidak terjadi. Mengapa? Karena selama ini dalam menerapkan pendekatan education production function terlalu memusatkan pada input pendidikan dalam hal ini guru yang mengikuti kegiatan MGMP dan berusaha memperhatikan pada proses kinerja. Padahal, proses kinerja sangat menentukan output kegiatan MGMP. Faktor kedua, penyelenggaraan MGMP yang dilakukan masih dapat melepaskan dari sistem birokrasi pemerintah daerah, sehingga terkadang menempatkan MGMP sebagai wadah pengembangan profesionalisme guru masih tergantung pada keputusan birokrasi yang mempunyai jalur yang sangat panjang dan kadang-kadang kebijakan yang dikeluarkan tidak sesuai dengan kebutuhan guru setempat. Dengan demikian MGMP kehilangan kemandirian, motivasi dan insiatif untuk mengembangkan dan memajukan lembaganya termasuk peningkatan profesionalisme guru sebagai salah satu faktor yang mempengaruhi mutu pendidikan nasional. Faktor ketiga, akuntabilitas kinerja MGMP selama ini dilakukan dengan baik. Pengurus MGMP memiliki beban untuk mempertanggungjawabkan hasil pelaksanaan kegiatannya kepada sesama rekan 
guru, pimpinan sekolah, dan masyarakat. Faktor peranan MGMP keempat,sudah adanya panduan/ petunjuk kegiatan kelompok kerja yang jelas untuk dapat digunakan sebagai acuan bagi guru dan pengurus MGMP dalam melakukan aktivitas kelompok kerja atau musyawarah kerja. 10 Adanya peningkatan profesionalisme guru PAI SMA di Kabupaten Jombang setelah mereka bergabung dan berpartisipasi aktif dalam kegiatan MGMP dapat dilihat dari kondisi sebagai berikut: Pertama, Tumbuhnya kemauan para guru PAI untuk selalu membenahi kinerjanya sebagai seorang guru dengan mengikuti perubahan-perubahan positif yang ada. Kedua, Guru PAI termotivasi untuk menjadi lebih baik karena banyak bersinggungan dengan orang lain sehingga wawasan menjadi bertambah. Ketiga, Para guru PAI mengetahui berita atau isu-isu terbaru di dunia pendidikan karena MGMP adalah sebagai mediator dari Dinas Pendidikan Nasional dan Departemen Agama dalam penyampaian kebijakan pendidikan, perubahan kurikulum, dan lain-lain. Keempat, Dengan adanya training dan penataran maka kreatifitas dan skill guru PAI akan semakin tumbuh dan terasah. Dengan demikian, memungkinkan terwujudnya ide-ide terbaru dan upaya peningkatan profesionalisme secara terus-menerus. Kelima, Guru PAI setelah mengikuti MGMP menjadi mahir dalam membuat perangkat pembelajaran seperti: rencana pelaksanaan pembelajaran (RPP), portofolio, program semester (promes), program tahunan (protan) dan lain-lain. Keenam, Adanya kesadaran dan

\footnotetext{
${ }^{10}$ Direktorat Profesi Pendidik, "Standar Pengembangan," Standar Pengembangan KKG dan MGMP (2008): 0-32.
} 


\section{Muhamad Khoirur Roziqin, Sholeh Abdul Baqi.}

keinginan untuk dapat menggunakan media pembelajaran yang berbasis teknologi informasi sehingga selain menguasai mata pelajaran, guru PAI juga tidak gagap dalam teknologi.

Peran MGMP Mata Pelajaran PAI SMA Di Kabupaten Jombang dalam proses peningkatan profesionalisme Guru yang dilakukan dengan mekanisme yang dibangun oleh pengurus serta guru-guru anggota yang bergabung dalam forum organisasi. Pelaksanaannya sangat membantu guru dalam perencanaan konsep pembelajaran. Peranan Musyawarah Guru Mata Pelajaran (MGMP) Guru PAI SMA Kabupaten Jombang dapat menambah kualitas pembelajaran. Hasil penelitian, dilakukan pertama dalam melaksanakan tugas (bersifat konservatif), mengingat cara yang dipandang baru menuntut perubahan dalam pola-pola kerja. Kedua Kurang adanya motivasi untuk selalu meningkatkan kinerja diri atau profesionalisme. Ketiga Minimnya pengetahuan dan wawasan guru PAI tentang info atau berita terbaru dunia pendidikan (isu-isu edukatif). Keempat Kurangnya kreatifitas dan skill (keahlian) guru PAI dalam mengembangkan materi pelajaran. Kelima Masih banyaknya guru PAI di lapangan yang belum melengkapi administrasi pembelajaran dan sebagian para guru PAI terkadang masih menggantungkan silabus yang dibuat oleh tim MGMP. Keenam Sebagian para guru PAI belum bisa menerima perubahan dalam pembelajaran, misalnya dalam hal penguasaan teknologi dan informasi. Indikator peningkatan profesionalisme 
guru PAI setelah mengikuti kegiatan MGMP.11 Adanya peningkatan profesionalisme guru PAI SMA di Kabupaten Jombang setelah mereka bergabung dan berpartisipasi aktif dalam kegiatan MGMP dapat dilihat dari kondisi sebagai berikut: Pertama, Tumbuhnya kemauan para guru PAI untuk selalu membenahi kinerjanya sebagai seorang guru dengan mengikuti perubahan-perubahan positif yang ada. Kedua, Guru PAI termotivasi untuk menjadi lebih baik karena banyak bersinggungan dengan orang lain sehingga wawasan menjadi bertambah. Ketiga, Para guru PAI mengetahui berita atau isu-isu terbaru di dunia pendidikan karena MGMP adalah sebagai mediator dari dinas pendidikan nasional dan departemen agama dalam penyampaian serta peran kegiatan kebijakan pendidikan,dan pelaksanaan perubahan kurikulum.

Peran serta dari hasil observasi bahwa adanya MGMP dalam peningkatan profesionalisme guru Mapel PAI di Jombang dilakukan dengan rapat guru, penataran guru, dan penyediaan sarana prasarana. ${ }^{12}$ Ketua MGMP PAI Jombang, KH Fakhruddin menyampaikan kondisi kekurangan guru PAI di SMA negeri. "Jika tidak dicarikan solusi, kekurangan guru dapat berdampak pada pemahamaan agama siswa. Sebab di beberapa sekolah, PAI diajarkan oleh guru umum. Berdasarkan hasil wawancara di atas dapat dipahami bahwa pelaksanaan

\footnotetext{
${ }^{11}$ Fachruddin Saudagar and Ali Idrus, "Pengembangan Profesionalitas Guru," 2011, 121.

${ }_{12}$ M.R Ridla, "Profesionalitas Guru Pendidikan Agama Islam Dalam Proses Pembelajaran," Tadris 3, no. 1 (2008): 30-44, http:// ejournal.iainmadura.ac.id/index.php/tadris/article/view/230\%0Ahttp://download.portalgar uda.org $/$ article.php?article=391611\&val=8582\&title=PROFESIONALITAS GURU PENDIDIKAN AGAMA ISLAM DALAM PROSES PEMBELAJARAN.
} 


\section{Muhamad Khoirur Roziqin, Sholeh Abdul Baqi.}

Musyawarah Guru Mata Pelajaran mulai sejak didirikannya dan sudah berjalan dengan semestinya. ${ }^{13}$ Dengan harapan bahwa dengan adanya Musyawarah Guru Mata Pelajaran ini dapat menunjang keberhasilan proses pembelajaran dengan baik sesuai dengan pembahasan mekanisme yang berlaku. Musyawarah guru juga memiliki peran terpenting di sekolah, hal ini dapat dilihat bagaimana guru melaksanakan agenda kerja untuk membahas proses pembelajaran di sekolah mulai dari RPP sampai dengan kurikulum sekolah,demi mewujudkan keberhasilan proses pembelajaran yang lebih efektif. Lanjut wawancara dengan Bapak Fakhrudin, M.Pd.I, mengenai pelaksanaan Musyawarah Guru Mata Pelajaran (MGMP) PAI beliau mengatakan bahwa: Dalam pelaksanaan Musyawarah Guru Mata Pelajaran (MGMP) PAI dilaksanakan secara berkelompok untuk membahas RPP dan proses pelaksanaan pembelajaran mata pelajaran PAI. Berdasarkan wawancara dengan Bapak Ahmad Zainuddin, M.MA mengenai efektifitas pelaksanaan Musyawarah Guru Mata Pelajaran (MGMP) PAI di Kabupaten Jombang beliau mengatakan bahwa: Pelaksanaan Musyawarah Guru Mata Pelajaran (MGMP) PAI sudah berjalan dengan baik sesuai dengan jadwal yang ditetapkan, kadang kala pertemuannya ditunda ketika para anggota banyak yang tidak hadir dikarenakan ada urusan penting. Organisasi dapat dikatakan efektif apabila memiliki dan memenuhi standar atau acuan sebagai landasan dalam melaksanakan program untuk mencapai visi, misi, dan

\footnotetext{
${ }^{13}$ Fakhruddin, "Wawancara Pribadi" (Jombang: Anggota Musyawarah Guru Mata Pelajaran (MGMP) PAI SMA, 2021).
} 
tujuan.Indikator efektifitas kinerja tersebut dapat dilihat dari kesesuaian antara standar pengembangan dan standard operasional penyelenggaraan, dengan kondisi Musyawarah Guru Mata Pelajaran dalam usahanya memenuhi standar tersebut.

\section{PEMBAHASAN}

\section{Tujuan Musyawarah Guru Mata Pelajaran (MGMP) PAI di Jombang}

Musyawarah Guru Mata Pelajaran merupakan suatu forum atau wadah profesional guru mata pelajaran yang berada pada suatu wilayah kabupaten/kota/kecamatan sanggar/gugus sekolah.14 Ruang lingkupnya meliputi guru mata pelajaran pada sekolah menengah atau sekolah menengah atas sederajat baik negeri dan swasta, baik yang berstatus Pegawai Negeri Sipil maupun swasta dan guru tidak tetap/honorarium. Prinsip kerjanya adalah cerminan kegiatan" dari, Oleh dan untuk Guru" dari semua sekolah ${ }^{15}$. Atas dasar ini maka Musyawarah Guru Mata Pelajaran merupakan organisasi nonstruktural yang bersifat mandiri dan berasaskan kekeluargaan.

Tujuan diselenggarakannya Musyawarah Guru Mata Pelajaran ialah untuk memotifasi guru guna meningkatkan kemampuan dan keterampilan dalam merencanakan, melaksanakan, dan membuat Evaluasi program pembelajaran dalam rangka meningkatkan keyakinan diri sebagai guru professional dan untuk

\footnotetext{
${ }^{14}$ Nur Halija, "Peranan Musyawarah Guru Mata Pelajaran (Mgmp) Aqidah Akhlak Dalam Meningkatkan Kualitas Pembelajaran Di Mts. Muallimin Muhammadiyah Cab. Makassar" (Universitas Muhammadiyah Makasar, 2019).

${ }^{15}$ Ibid.
} 


\section{Muhamad Khoirur Roziqin, Sholeh Abdul Baqi.}

menyatakan kemampuan dan kemahiran guru. Tujuan lain dari Musyawarah Guru Mata Pelajaran adalah memperluas wawasan dan pengetahuan guru dalam hal, khususnya penguasaan substansi materi pembelajaran, penyusunan silabus, penyusunan bahan pembelajaran, strategi pembelajaran, metode pembelajaran, memaksimalkan pemakaian sarana/prasarana belajar, memanfaatkan sumber

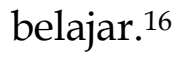

Dari penjelasan diatas ketua Musyawarah Guru Mata Pelajaran Pendidikan Agama Islam Jombang dapat menjelaskan beberapa tujuan. Tujuan pembentukan Musyawarah Guru Mata Pelajaran menurut bapak Fakhruddin yang tertuang dalam Standar Pengembangan Musyawarah Guru Mata Pelajaran adalah sebagai berikut:

a. Memperluas wawasan dan pengetahuan guru dalam berbagai hal, khususnya penguasaan substansi materi pelajaran, penyusunan silabus, penyusunan bahanbahan pembelajaran, strategi pembelajaran, metode pembelajaran, memaksimalkan pemakaian sarana/prasarana belajar, memanfaatkan sumber belajar;

b. Memberi kesempatan kepada anggota kelompok kerja atau musyawarah kerja untuk berbagi pengalaman serta saling memberikan bantuan dan umpan balik;

\footnotetext{
16 Ibid.
} 
c. Meningkatkan pengetahuan dan keterampilan, serta mengadopsi pendekatan pembaharuan dalam pembelajaran yang lebih profesional bagi peserta kelompok kerja atau musyawarah kerja;

d. Memberdayakan dan membantu anggota kelompok kerja dalam melaksanakan tugas-tugas pembelajaran di sekolah;

e. Mengubah budaya kerja anggota kelompok kerja atau musyawarah kerja (meningkatkan pengetahuan, kompetensi dan kinerja) dan mengembangkan profesionalisme guru melalui kegiatan-kegiatan pengembangan profesionalisme di tingkat Musyawarah Guru Mata Pelajaran;

f. Meningkatkan mutu proses pendidikan dan pembelajaran yang tercermin dari peningkatan hasil belajar peserta didik;

g. Meningkatkan kompetensi guru melalui kegiatan-kegiatan di tingkat Musyawarah Guru Mata Pelajaran.

Berdasarkan tujuan diatas, maka beberapa fungsi yang diemban Musyawarah Guru Mata Pelajaran yaitu:

a. Menyusun program jangka panjang, jangka menengah, dan jangka pendek, serta mengatur jadwal dan tempat kegiatan secara rutin.

b. Memotivasi para guru untuk mengikuti kegiatan Musyawarah Guru Mata Pelajaran secara rutin, baik ditingkat sekolah maupun kabupten. 


\section{Muhamad Khoirur Roziqin, Sholeh Abdul Baqi.}

c. Meningkatkan mutu kompetensi profesionalisme guru dalam perencanaan, pelaksanaan, dan pengujian/evaluasi pembelajaran dikelas, sehingga mampu mengupayakan peningkatan dan pemerataan mutu pendidikan di sekolah.

d. Mengembangkan program layanan supervisi akademik klinis yang berkaitan dengan pembelajaran yang efektif. ${ }^{17}$

\section{Peran MGMP PAI SMA di Jombang}

Peran MGMP dalam peningkatan profesionalisme guru di Jombang dilakukan dengan rapat guru, penataran guru,pelatihan guru profesional dan penyediaan sarana prasarana. Ketua MGMP PAI Jombang Fakhruddin menyampaikan kondisi kekurangan guru PAI di sekolah-sekolah negeri. “Jika tidak dicarikan solusi, kekurangan guru dapat berdampak pada pemahamaan agama siswa. Sebab di beberapa sekolah, PAI diajarkan oleh guru umum. ${ }^{18}$

Berdasarkan hasil wawancara di atas dapat dipahami bahwa pelaksanaan Musyawarah Guru Mata Pelajaran mulai sejak didirikannya dan sudah berjalan dengan semestinya. Dengan harapan bahwa dengan adanya MGMP ini dapat menunjang keberhasilan proses pembelajaran dengan baik sesuai dengan pembahasan mekanisme yang berlaku. Musyawarah guru juga memiliki peran terpenting di sekolah, hal ini dapat dilihat bagaimana guru melaksanakan agenda kerja untuk membahas proses pembelajaran di sekolah mulai dari RPP sampai dengan kurikulum demi mewujudkan keberhasilan proses pembelajaran yang

\footnotetext{
17 Ibid.

18 Kemenag Jombang, "Kunjungi Kemenag, MGMP PAI Jombang Curhat Kekurangan Guru Agama."
} 
lebih efektif. Lanjut wawancara dengan Bapak Fakhrudin, M.Pd.I, mengenai pelaksanaan MGMP PAI beliau mengatakan bahwa: Dalam pelaksanaan MGMP PAI dilaksanakan secara berkelompok untuk membahas RPP dan proses pelaksanaan pembelajaran mata pelajaran PAI. ${ }^{19}$ Berdasarkan wawancara dengan Bapak Ahmad Zainuddin, M.MA mengenai efektifitas pelaksanaan MGMP PAI di Kabupaten Jombang beliau mengatakan bahwa: Pelaksanaan MGMP PAI sudah berjalan dengan baik sesuai dengan jadwal yang ditetapkan, kadang kala pertemuannya ditunda ketika para anggota banyak yang tidak hadir dikarenakan ada urusan penting. Organisasi dapat dikatakan efektif apabila memiliki dan memenuhi standar atau acuan sebagai landasan dalam melaksanakan program untuk mencapai visi, misi, dan tujuan.Indikator efektifitas kinerja tersebut dapat dilihat dari kesesuaian antara standar pengembangan dan standard operasional penyelenggaraan, dengan kondisi MGMP dalam usahanya memenuhi standar tersebut. ${ }^{20}$

\section{Peranan MGMP dalam Peningkatan Profesional Guru PAI di Jombang}

Berdasarkan wawancara dengan ketua MGMP PAI SMA tingkat Jombang mengatakan bahwa pertama kurang adanya motivasi untuk selalu meningkatkan kinerja diri atau profesionalisme. Kedua minimnya pengetahuan dan wawasan guru PAI tentang info atau berita terbaru dunia pendidikan (isu-isu edukatif). Ketiga Kurangnya kreatifitas dan skill (keahlian) guru PAI dalam

\footnotetext{
${ }^{19}$ Fakhruddin, "Wawancara Pribadi."

20 Zainuddin, "Wawancara Pribadi" (Jombang: Anggota Musyawarah Guru Mata Pelajaran (MGMP) PAI SMA, 2021).
} 


\section{Muhamad Khoirur Roziqin, Sholeh Abdul Baqi.}

mengembangkan materi pelajaran. Kelima Masih banyaknya guru PAI di lapangan yang belum melengkapi administrasi pembelajaran dan sebagian para guru PAI terkadang masih menggantungkan silabus yang dibuat oleh tim MGMP. Kelima Sebagian para guru PAI belum bisa menerima perubahan dalam pembelajaran, misalnya dalam hal penguasaan teknologi dan informasi. Indikator peningkatan profesionalisme guru PAI setelah mengikuti kegiatan MGMP. Adanya peningkatan profesionalisme guru PAI SMA di Kabupaten Jombang setelah mereka bergabung dan berpartisipasi aktif dalam kegiatan MGMP dapat dilihat dari kondisi sebagai berikut: Pertama, Tumbuhnya kemauan para guru PAI untuk selalu membenahi kinerjanya sebagai seorang guru dengan mengikuti perubahan-perubahan positif yang ada. Kedua, Guru PAI termotivasi untuk menjadi lebih baik karena banyak bersinggungan dengan orang lain sehingga wawasan menjadi bertambah. Ketiga, Para guru PAI mengetahui berita atau isuisu terbaru di dunia pendidikan karena MGMP adalah sebagai mediator dari dinas pendidikan nasional dan departemen agama dalam penyampaian kebijakan pendidikan, perubahan kurikulum, dan lain-lain. Keempat, Dengan adanya training dan penataran maka kreatifitas dan skill guru PAI akan semakin tumbuh dan terasah.

Dengan demikian, memungkinkan terwujudnya ide-ide terbaru dan upaya peningkatan profesionalisme secara terus-menerus. Kelima, Guru PAI setelah mengikuti MGMP menjadi mahir dalam membuat perangkat 
pembelajaran seperti: rencana pelaksanaan pembelajaran (RPP), portofolio, program semester (promes), program tahunan (protan) dan lain-lain. Keenam, Adanya kesadaran dan keinginan untuk dapat menggunakan media pembelajaran yang berbasis teknologi informasi sehingga selain menguasai mata pelajaran, guru PAI juga tidak gagap dalam teknologi.

\section{E. KESIMPULAN}

Peran MGMP PAI SMA Tingkat Kabupaten Jombang dalam proses pengembangan serta peningkatan profesionalisme Guru dilakukan dengan mekanisme yang dibangun oleh pengurus serta guru-guru anggota yang bergabung. Pelaksanaannya sangat membantu guru dalam perencanaan konsep pembelajaran. Peranan Musyawarah Guru Mata Pelajaran (MGMP) Guru PAI SMA Kabupaten Jombang dapat menambah kualitas dalam pengembangan pembelajaran. Dari hasil pengamatan dan anailsis, sedikitnya ada empat faktor yang menyebabkan kinerja MGMP secara umum tidak mengalami peningkatan secara merata. Adanya peningkatan profesionalisme guru PAI SMA di Kabupaten Jombang setelah mereka bergabung dan berpartisipasi aktif dalam kegiatan MGMP dapat dilihat dari kondisi sebagai berikut: Pertama, Tumbuhnya kemauan para guru PAI untuk selalu membenahi kinerjanya sebagai seorang guru dengan mengikuti perubahan-perubahan positif yang ada. Kedua, Guru PAI termotivasi untuk menjadi lebih baik karena banyak bersinggungan dengan orang lain sehingga wawasan menjadi bertambah. Ketiga, Para guru PAI mengetahui berita 


\section{Muhamad Khoirur Roziqin, Sholeh Abdul Baqi.}

atau isu-isu terbaru di dunia pendidikan karena MGMP adalah sebagai mediator dari dinas pendidikan nasional dan departemen agama dalam penyampaian kebijakan pendidikan, perubahan kurikulum, dan lain-lain. Keempat, Dengan adanya training dan penataran maka kreatifitas dan skill guru PAI akan semakin tumbuh dan terasah. Dengan demikian, memungkinkan terwujudnya ide-ide terbaru dan upaya peningkatan profesionalisme secara terus-menerus. Kelima, Guru PAI setelah mengikuti MGMP menjadi mahir dalam membuat perangkat pembelajaran seperti: rencana pelaksanaan pembelajaran (RPP), portofolio, program semester (promes), program tahunan (protan) dan lain-lain. Keenam, Adanya kesadaran dan keinginan untuk dapat menggunakan media pembelajaran yang berbasis teknologi informasi sehingga selain menguasai mata pelajaran, guru PAI juga tidak gagap dalam teknologi.

\section{F. DAFTAR PUSTAKA}

Tegeh, Made, Nyoman Jampel, Ketut Putdjawen. (2015). Pengembangan Buku Ajar Model Penelitian Pengembangan Dengan Model ADDIE. Jurusan teknologi pendidikan FIP Undiksha.

Depdiknas. “Panduan Pengembangan Bahan Ajar Depdiknas 2008” (2008): 1-4.

Fakhruddin. "Wawancara Pribadi." Jombang: Anggota Musyawarah Guru Mata Pelajaran (MGMP) PAI SMA, 2021.

Halija, Nur. “Peranan Musyawarah Guru Mata Pelajaran (Mgmp) Aqidah Akhlak Dalam Meningkatkan Kualitas Pembelajaran Di Mts. Muallimin Muhammadiyah Cab. Makassar." Universitas Muhammadiyah Makasar, 2019.

Kalimantara, Asep, S D Negeri, Nugara Pelita, and Jalancagak Subang. Kompetensi Kewirausahaan Kepala Sekolah Dan Implikasinya Pada 
Peningkatan Mutu Guru Dalam Pembelajaran Di SD Negeri Nugraha Pelita Jalancagak Kabupaten Subang. Jurnal Penelitian Guru FKIP Universitas Subang. Vol. 03, n.d.

Kemenag Jombang. "Kunjungi Kemenag, MGMP PAI Jombang Curhat Kekurangan Guru Agama."

Langgau, and Yulius Mataputun. "Peranan Mgmp Dalam Meningkatkan Profesionalisme Guru Bahasa Inggris SMP Di Kota Jayapura." Jurnal MAPENDIK-Magister Manajemen Pendidikan Uncen 03, no. 01 (2016): 8188.

Pendidik, Direktorat Profesi. "Standar Pengembangan." Standar Pengembangan KKG dan MGMP (2008): 0-32.

Ridla, M.R. "Profesionalitas Guru Pendidikan Agama Islam Dalam Proses Pembelajaran." Tadris 3, no. 1 (2008): 30-44. http://ejournal.iainmadura.ac.id/index.php/tadris/article/view/230\% 0Ahttp:/ / download.portalgaruda.org/article.php?article=391611\&val= 8582\&title=Profesionalitas Guru Pendidikan Agama Islam Dalam Proses Pembelajaran.

Saudagar, Fachruddin, and Ali Idrus. "Pengembangan Profesionalitas Guru," 2011.

Sugiyono. Metode Penelitian Kuantitatif, Kualitatif Dan RED. Edited by IKAPI. Bandung: Bandung: Alfabeta, 2016.

Zainuddin. "Wawancara Pribadi." Jombang: Anggota Musyawarah Guru Mata Pelajaran (MGMP) PAI SMA, 2021.

Zulfah, Machnunah Ani. "Pendidikan Seks Pada Anak Dalam Islam." At-Tahdzib Jurnal Studi Islam dan Muamalah 1, no. 1 (2017): 150-171.

“Peranan MGMP Dalam Ikan Agama Islam SMA Di," n.d.

Undang-Undang Sistem Pendidikan Nasional Guru Dan Dosen. Tangerang: PT. Agro Media Pustaka, 2007. 
Muhamad Khoirur Roziqin, Sholeh Abdul Baqi.

76 | E-ISSN : 2548-6896, P-ISSN : 2597-4858

Dinamika Vol. 6, No. 1, Juni 2021 